\title{
JENIS-JENIS DAN KEPADATAN IKAN KARANG DI PULAU PENATA BESAR, LEMUKUTAN, DAN PULAU KABUNG, PERAIRAN KALIMANTAN BARAT
}

\author{
Isa Nagib Edrus'), Yudi Siswantoro²), dan Imam Suprihanto ${ }^{3)}$ \\ 1) Staf Peneliti pada Balai Pengkajian Teknologi Pertanian, Maluku \\ 2) Staf Peneliti pada Pusat Survei Sumber Daya Alam Laut, BAKOSURTANAL \\ 3) Counterpart Peneliti dari LSM
}

\begin{abstract}
ABSTRAK
Penelitian yang dilakukan pada bulan Juni 2004 ini bertujuan untuk mendapatkan data dan informasi ikanikan yang hidup dan berasosiasi dengan karang serta memprediksi faktor-faktor penghambat yang mempengaruhi keberadaan di wilayah perairan pulau-pulau kecil di Kalimantan Barat. Metode yang digunakan adalah sensus visual pada transek garis. Hasil penelitian menunjukkan bahwa jumlah jenis ikan karang berkisar antara 36 sampai dengan 51 jenis dengan kepadatan antara 10 sampai dengan 15 individu per $\mathrm{m}^{2}$. Rata-rata untuk Indeks keanekaragaman jenis (H), Indeks Dominasi (D), Indeks Keseimbangan (E), dan Irian Jaya Reef Diversity Index masing-masing 2,7; 0,1; 0,7; dan 4,5. Persentase ikan kelompok mayor rata-rata 66\%, kelompok ikan target $19 \%$, dan kelompok ikan indikator $15 \%$. Sedangkan rata-rata persentase penggolongan ikan berdasarkan pada nilai ekonomi $66 \%$ ikan ekonomis rendah, 17\% ikan ekonomis sedang, dan $17 \%$ ikan ekonomis tinggi. Faktor pembatas distribusi ikan adalah kekeruhan air yang cukup tinggi yang disebabkan oleh sedimen dari daratan.
\end{abstract}

\section{KATA KUNCI: jenis-jenis, kepadatan, ikan karang, Kalimantan Barat}

ABSTRACT: The kinds and density of the coral fishes of Penata Besar, Lemukutan, and Kabung Islands in the coastal waters of West Kalimantan. By: Isa Nagib Edrus, Yudi Siswantoro, and Imam Suprihanto

A study conducted in June 2004 aims to obtain data and information of fish living on and associating to coral reefs, and also to assume limitting factors for fish distribution. A sampling method used was visual census on a transect line. The result shows that the number of coral fish ranged from 36 to 51 species. The density of coral fish ranged from 10 to 15 indivdual per $m^{2}$. The means of Diversity Indeces (H), Dominance Indeces (D), Eveness Indeces, and Irian Jaya Reef Diversity Index indeces were 2.7; 0.1; 0.7; and 4.5, respectively. The percentages of a major fish group, a target fish group, and an indicator fish group were average of 66, 19, and 15\%, respectively. The mean percentages of marketable based fish groups consisted of $66 \%$ of low valuable fishes, $17 \%$ of fair valuable fishes, and $17 \%$ of high valuable fishes. The low level of body water transfarancy due to upland sediment was a limitting factor for the attendance of coral fish in the coral reef area of study sites.

KEYWORDS: $\quad$ species, density, coral fish, West Kalimantan

\section{PENDAHULUAN}

Keanekaragaman ikan karang di suatu terumbu karang bukan hanya memberikan nilai estetika bagi pariwisata bahari, tetapi juga memberikan sediaan sumber daya hayati dan pendapatan bagi masyarakat sekitar. Terumbu karang menyediakan ikan hias laut dan ikan pangan, yang ke-2 merupakan asset bagi daerah dalam upaya pengembangan usaha perikanan dan ketahanan pangan. Oleh karena itu, pemerintah daerah sebagai otoritas dalam era otonomi daerah menaruh harapan besar atas potensi sumber daya terumbu karang. Kutzmann (2004) mengatakan bahwa di beberapa negara berkembang, terumbu karang menyediakan $25 \%$ dari total sediaan makanan dan $60 \%$ dari total kebutuhan protein hewani.

Pengelolaan sumber daya terumbu karang penuh menjadi tanggung jawab pemerintah daerah. Tidak sedikit data dan informasi dibutuhkan untuk kepentingan ini. Ketidakberuntungan bahwa usaha pengumpulan dan pembangunan jaringan data dan informasi sumber daya pada umumnya kalah cepat dibanding laju proses degradasi sumber daya yang menjadi obyek pembangunan. Sehingga sebelum dilakukan pendataan dan pengelolaan, banyak sumber daya yang hilang siasia yang berakhir pada erosi genetik. Pada hal perairan Indonesia yang terletak pada wilayah tropis memiliki

Kosrespondensi penulis:

Jl. Chr. Soplanit-Rumat Tiga, Ambon 97233, Kotak Pos: 204 PASSO 
biodiversitas ikan yang sangat tinggi. Menurut White (1987), 40\% jenis ikan laut yang taksonomi telah diketahui di dunia, yaitu kira-kira 8.000 spesies, hidup di perairan hangat sampai dengan kedalaman $200 \mathrm{~m}$. Dibanding perairan di lahan sub tropis, perairan tropis dekat karang atau di lahan karang dihuni oleh lebih beragam jenis ikan walaupun lebih sedikit individu ikan dalam tiap jenis. Menurut Kunzmann (2004), di Asia Tenggara terdapat banyak jenis dalam setiap unit lahan, yaitu kira-kira ada 400 jenis fauna pembangun terumbu karang, lebih dari 3.000 jenis ikan karang, dan kira-kira 1.700 moluska terdapat di wilayah ini.

Kelemahan pemerintah daerah dalam pengelolaan sumber daya terumbu karang pada umumnya berkaitan dengan 1) belum penuh visi dan strategi otonomi daerah dilaksanakan untuk kepentingan proteksi dan pelestarian lingkungan; 2) lemah pola perencanaan pembangunan pesisir dan pulau-pulau kecil; 3) kecil porsi perhatian dan pendanaan atas proses monitoring dan evaluasi sumber daya; 4) rendah jumlah dan kapasitas sumber daya manusia; dan 5) terbatas kesempatan partisipasi masyarakat dalam pengelolaan. Contoh yang paling menonjol adalah model perencanaan pembangunan lebih berbasis kontinental daripada berbasis kepulauan. Sehingga semua dampak negatif pembangunan di daratan ditanggung oleh pesisir dan pulau-pulau kecil.

Peningkatan jumlah penduduk dan pembangunan ekonomi memiliki pengaruh langsung pada sumber daya pantai. Kegiatan manusia bersama-sama dengan pengaruh alam atau biologis memberikan andil terhadap degradasi sumber daya terumbu karang yang merupakan dampak negatif, seperti kerusakan habitat, degradasi biologis, penurunan turbiditas dan kecerahan massa air, dan perubahan keseimbangan ekosistem.

Secara alami, terumbu karang memberikan kapasitas yang besar untuk flora dan fauna yang hidup dan tumbuh di dalam. Konsep relung ekologi (ecology niche) telah menggambarkan bagaimana ekosistem terumbu karang menciptakan keanekaragaman jenis biota yang tinggi (Lieske \& Myers, 1997). Banyak jenis ikan karang pemakan karang memperlihatkan perilaku teritorial dan mobilitas yang sempit di sekitar karang, di mana banyak di antara ikan karang tidak pergi jauh dari sumber makanan dan tempat perlindungan. Seperti diketahui bahwa struktur terumbu karang menyediakan beragam liang, lubang, dan gua yang digunakan sebagai tempat berlindung (shelter). Jadi batasan teritorial bagi ikan karang lebih didasarkan pada sediaan makanan, pola pemijahan (spawning), ancaman predator, kebutuhan ruang dan lain-lain, semua menambah kompleksitas dan harmonis hubungan ikan di dalam lahan terumbu karang.
Namun, faktor eksternal sering kali mengganggu fungsi masing-masing organisme karang, bahkan secara menyeluruh mengganggu fungsi ekosistem terumbu karang sehingga tercipta ketidakseimbangan di dalam ekosistem tersebut. Contoh polusi kimia dan sedimen pada massa air laut dan atau peningkatan suhu yang ekstrim akibat anomali iklim (El Niño). Dengan demikian, generalisasi yang mengatakan bahwa terumbu karang kaya akan ikan menjadi berbeda antara daerah yang satu dengan daerah yang lain. Ikan karang merupakan indikator yang baik untuk menggambarkan pengaruh polusi tersebut pada lahan yang terkena dampak. Dari kenyataan ini akan timbul pertanyaan bahwa sejauh mana lahan terumbu karang dapat memberikan kapasitas daya dukung pada ikan karang pada wilayah-wilayah di sekitar muara sungai besar yang memiliki potensi besar pada polusi sedimen?

Beberapa parameter komunitas antara lain keanekaragaman jenis, tingkat dominasi, keseimbangan populasi, dan kelimpahan jenis banyak digunakan untuk keperluan monitoring dan evaluasi sumber daya hayati ikan karang. Komunitas ikan sangat beragam dan unik dalam suatu perairan karang. Informasi komunitas ikan memberikan gambaran mengenai karakteristik ekosistem perairan terumbu karang dan bermanfaat untuk kepentingan pengembangan dan pengelolaan.

Tujuan penelitian ini adalah untuk mendapatkan data dan informasi ikan-ikan yang hidup dan berasosiasi dengan karang serta memprediksi faktor-faktor penghambat yang mempengaruhi keberadaan di wilayah perairan pulau-pulau kecil di Kalimantan Barat. Hasil penelitian diharapkan dapat menjadi bahan pertimbangan perumusan kebijakan daerah dalam pengelolaan dan pengembangan potensi sumber daya ikan karang.

\section{BAHAN DAN METODE}

\section{Waktu dan Lokasi Penelitian}

Kegiatan survei lapang dilaksanakan pada bulan Juni 2004 di wilayah perairan karang Pulau-Pulau Penata Besar, Lumukutan, dan Pulau Kabung, Kabupaten Bengkayang, Kalimantan Barat. Pulau tersebut terletak di antara lintang koordinat geografi $00^{\circ} 40^{\prime} 00^{\prime \prime}-00^{\circ} 51^{\prime} 00^{\prime \prime}$ LS dan 108 $40^{\circ} 00^{\prime \prime}-108^{\circ} 50^{\prime} 00^{\prime \prime}$ BT (Gambar 1 dan Tabel $1)$.

\section{Metode}

Survei ini dilakukan dengan pendekatan sensus visual pada garis transek (English et al., 1994). Data ikan karang diperoleh dengan sensus visual yang 
dikerjakan oleh penyelam sepanjang garis transek 100 $m$, dengan luas lahan sensus $(100 \times 5) \mathrm{m}^{2}$. Jenis dan perkiraan jumlah ikan dicatat dalam data sheet kedap air. Identifikasi jenis ikan menggunakan buku petunjuk bergambar (Kuiter, 1992; Lieske \& Myers, 1997). Ikan karang dikelompokkan menurut status, seperti ikan indikator, ikan mayor, dan ikan target (English et al.,
1994). Ikan indikator kebanyakkan dari suku Chaetodontidae yang kehadirannya dapat merefleksikan kondisi kesehatan karang. Ikan mayor adalah golongan ikan hias dan non ikan hias yang selalu berasosiasi dengan karang, baik sebagai penetap maupun pelintas. Ikan target adalah dari golongan ikan yang dicari oleh nelayan untuk dimakan dan dijual.

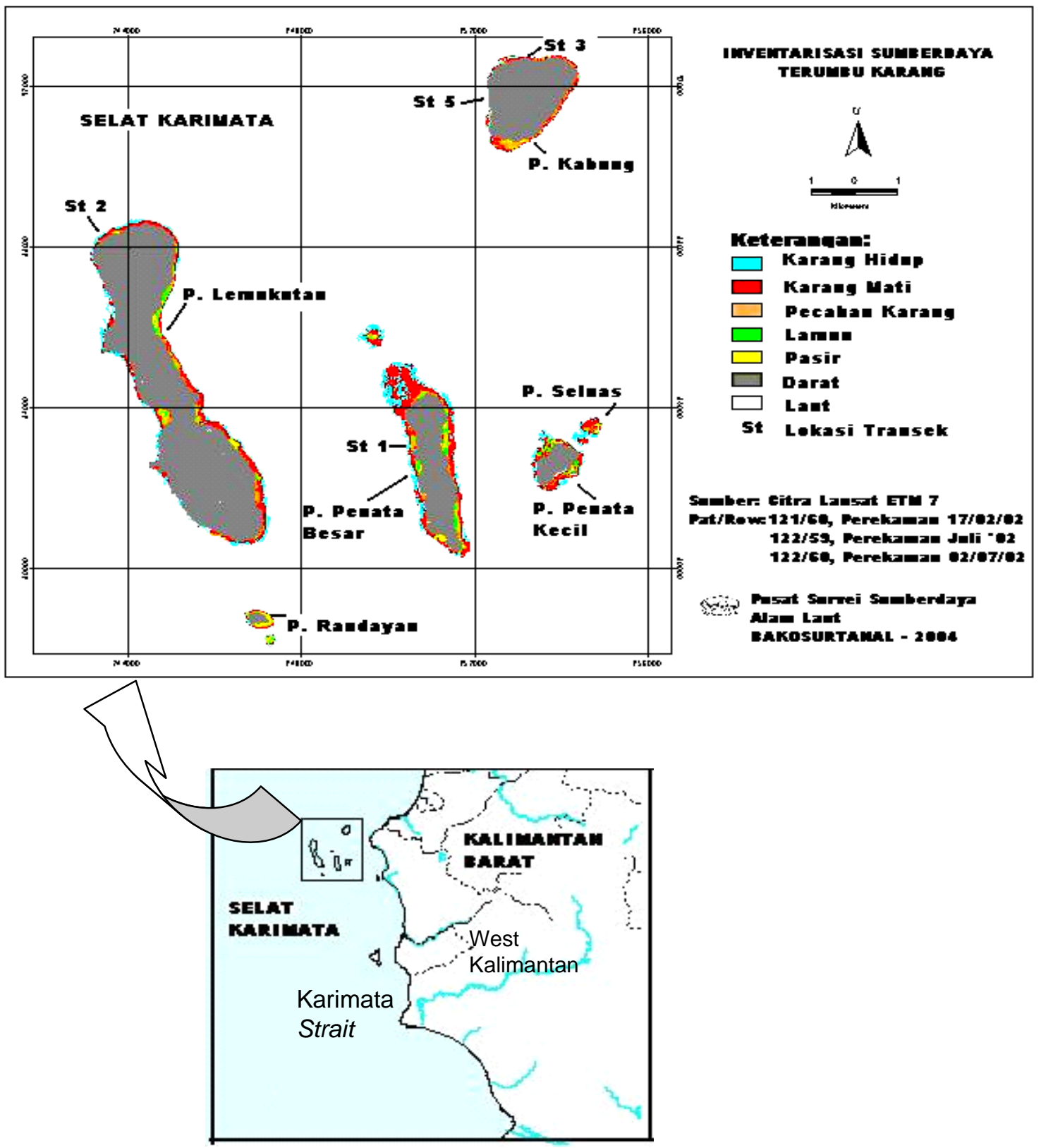

Gambar 1. Peta lokasi penelitian hasil interpretasi dari citra Landsat ETM-7 hasil perekaman tahun 2002. Sumber: Bakosurtanal, 2004

Figure 1. The study site map derived from the 2002 recording of $7^{\text {th }}$ ETM Landsat Citra.

Source: Bakosurtanal, 2004 
Tabel 1. Gambaran umum lokasi transek pada setiap stasiun

Table 1. A common description of study sites by stations

\begin{tabular}{|c|c|c|c|c|c|}
\hline $\begin{array}{l}\text { Stasiun } \\
\text { (Station) }\end{array}$ & $\begin{array}{c}\text { Posisi } \\
\text { geografis } \\
\text { transek } \\
\text { (Geographical } \\
\text { position of the } \\
\text { transects) } \\
\end{array}$ & $\begin{array}{l}\text { Dasar perairan } \\
\text { dan persentasi } \\
\text { tutupan karang*) } \\
\text { (Sea bottom and } \\
\text { percent cover of } \\
\text { corals) }\end{array}$ & $\begin{array}{c}\text { Jarak } \\
\text { pandang } \\
\text { horisontal } \\
\text { (Body water } \\
\text { visibility) }\end{array}$ & $\begin{array}{l}\text { Arus air } \\
\text { (Water } \\
\text { current) }\end{array}$ & $\begin{array}{l}\text { Nama lokasi } \\
\text { (Study site) }\end{array}$ \\
\hline 1 & $\begin{array}{l}\text { S } 00^{\circ} 45^{\prime} 77,9^{\prime \prime} \\
\text { E } 108^{\circ} 45^{\prime} 54,3^{\prime \prime}\end{array}$ & $\begin{array}{l}\text { Reef slope, batuan } \\
\text { vulkanik, pasir } \\
\text { lumpur, } \\
65,9 \% \text { tutupan } \\
\text { karang keras }\end{array}$ & $\begin{array}{l}\text { buruk } \\
(4 \mathrm{~m})\end{array}$ & Lemah & $\begin{array}{l}\text { Pulau Penata } \\
\text { Besar, } \\
\text { Berpenduduk, } \\
\text { Wilayah } \\
\text { Penangkapan ikan } \\
\text { teri }\end{array}$ \\
\hline 2 & $\begin{array}{l}\text { S } 00^{\circ} 48^{\prime} 07,0^{\prime \prime} \\
\text { E } 108^{\circ} 41^{\prime} 56,0^{\prime \prime}\end{array}$ & $\begin{array}{l}\text { Reef slope, batuan } \\
\text { vulkanik, pasir } \\
65,8 \% \text { tutupan } \\
\text { karang keras }\end{array}$ & $\begin{array}{l}\text { buruk } \\
(6 \mathrm{~m})\end{array}$ & Lemah & $\begin{array}{l}\text { Pulau Lemukutan } \\
\text { Berpenduduk, } \\
\text { Wilayah } \\
\text { Penangkapan ikan } \\
\text { teri }\end{array}$ \\
\hline 3 & $\begin{array}{l}\text { S } 00^{\circ} 50^{\prime} 24,0^{\prime \prime} \\
\text { E } 108^{\circ} 47^{\prime} 04,0^{\prime \prime}\end{array}$ & $\begin{array}{l}\text { Reef slope, batuan } \\
\text { vulkanik, pasir } \\
\text { lumpur } \\
57,8 \% \text { tutupan } \\
\text { karang keras }\end{array}$ & $\begin{array}{l}\text { buruk } \\
(4 \mathrm{~m})\end{array}$ & Lemah & $\begin{array}{l}\text { Pulau Kabung } \\
\text { Berpenduduk, } \\
\text { Wilayah } \\
\text { Penangkapan ikan } \\
\text { teri }\end{array}$ \\
\hline 4 & $\begin{array}{l}\text { S 0049'76,7" } \\
\text { E } 108^{\circ} 46^{\prime} 46,8^{\prime \prime}\end{array}$ & $\begin{array}{l}\text { Reef slope, batuan } \\
\text { vulkanik, pasir } \\
\text { lumpur, } \\
78,9 \% \text { tutupan } \\
\text { karang keras }\end{array}$ & $\begin{array}{l}\text { buruk } \\
(3,5 \mathrm{~m})\end{array}$ & Sedang & $\begin{array}{l}\text { Pulau Kabung } \\
\text { Berpenduduk, } \\
\text { Wilayah } \\
\text { Penangkapan ikan } \\
\text { teri }\end{array}$ \\
\hline
\end{tabular}

Keterangan/Remarks: ") = diperoleh pada waktu survei yang sama dengan mengunakan metode sampling line intercept transect Sumber/Source: Hasil Survei Lapang, bulan Juni 2004 (the 2004 June 2004 field survey)

\section{Analisis Data Ikan Karang}

Analisis keragaman hayati ikan karang menggunakan beberapa indeks yang dianggap penting sebagai base line data. Indeks-indeks itu adalah Indeks Kekayaan Jenis (Richness Indices), Indeks Keanekaragaman (Diversity Indices), dan Indeks Keseimbangan (Evenness Indices) (Ludwig \& Reynold, 1988).

Indeks Kekayaan Jenis (Richness Indices) mengacu pada:

1. Indeks Margalef $\left[\mathrm{R}_{1}=(\mathrm{S}-1) / \mathrm{ln}(\mathrm{n})\right]$

2. Indeks Menhinick $[\mathrm{R} 2=\mathrm{S} / \sqrt{ } \mathrm{n}]$

di mana:

$\mathrm{S}=$ banyak jenis

$\mathrm{n}=$ jumlah individu ikan untuk semua jenis

Indeks Keanekaragaman mengacu pada:

1. Indeks Simpson $\left[\lambda=\sum\left\{\left(\mathrm{n}_{\mathrm{i}}\left(\mathrm{n}_{\mathrm{i}}-1\right) /(\mathrm{N}(\mathrm{N}-1)\}\right]\right.\right.$

2. Indeks Shannon $\left[\mathrm{H}=\Sigma\left\{\left(\mathrm{n}_{\mathrm{i}} / \mathrm{N}\right) \ln \left(\mathrm{n}_{\mathrm{i}} / \mathrm{N}\right)\right\}\right]$ di mana:

$$
\begin{aligned}
& \mathrm{n}_{\mathrm{i}}=\text { jumlah ikan jenis ke-i } \\
& \mathrm{N}=\text { total individu ikan untuk semua jenis }
\end{aligned}
$$

Indeks Simpson adalah identik dengan Indeks Dominasi $[D=(1-H)]$, di mana nilai ke-2 indeks ini berbanding terbalik dengan Indeks Shannon. Semakin besar prediksi nilai dominasi terhadap komunitas biota, berarti semakin kecil nilai prediksi terhadap keanekaragaman komunitas tersebut. Dalam hal ini, keanekaragaman komunitas dianggap terbaik jika nilai $\lambda$ atau $D$ mendekati 0 dan terburuk jika nilai mendekati 1 (misalnya terjadi pada lingkungan hidup yang mengalami tekanan atau pencemaran). Berarti bahwa kisaran nilai ke- 2 Indeks ( $\lambda$ dan $D$ ) tersebut antara 0 dan 1 . Semakin mendekati nilai 0 , menyebabkan nilai Indeks $\mathrm{H}$ akan semakin besar (keanekaragaman hayati dianggap tinggi). Sebaliknya, semakin mendekati 1, menyebabkan nilai Indeks $\mathrm{H}$ semakin kecil (keanekaragaman hayati dianggap buruk). Dalam kondisi alamiah besarnya nilai Indeks $\mathrm{H}$ untuk komunitas ikan karang berkisar di antara nilai 3 (sedang). Dalam 
ekosistem yang matang seringkali nilai $\mathrm{H}$ menjadi>3. Dalam kondisi lingkungan yang buruk menyebabkan hanya sebagian kecil populasi biota yang bertahan dan menjadi berkembang mendominasi komunitas biota setempat. Ini berarti nilai Indeks Dominasi atau nilai Indeks Simpson untuk komunitas tersebut akan membesar dari 0 mendekati 1 dan akibatnya keanekaragaman $(\mathrm{H})$ mengecil dari 3 mendekati 1 . Selain itu, unsur yang membentuk keanekaragaman hayati juga ditinjau dari banyak populasi yang menonjol (melimpah atau paling melimpah). Keragaman populasi ini mengacu pada besarnya diversity number dari Hill yaitu $\mathrm{N}_{1}$ dan $\mathrm{N}_{2}$, di mana $\mathrm{N}_{1}$ ditafsirkan sebagai banyak populasi dari suatu spesies yang cukup melimpah, sedangkan $\mathrm{N}_{2}$ adalah banyak populasi dari suatu spesies yang paling melimpah.

Rumus:

$$
\begin{aligned}
& N_{1}=e^{H} \\
& N_{2}=1 / \lambda
\end{aligned}
$$

di mana:

$$
\begin{aligned}
& H=\text { Indeks Shannon } \\
& \lambda=\text { Indeks Sampson }
\end{aligned}
$$

Karena dominasi suatu populasi dalam komunitas juga mempengaruhi keseimbangan ekosistem, berarti besaran nilai Indeks Keanekaragaman $(\mathrm{H})$ bukan hanya tergantung pada nilai Indek Simpson atau Indeks Dominasi, tetapi juga sangat ditentukan oleh nilai Indeks Keseimbangan populasi dalam suatu komunitas. Karena itu, analisis data ini juga memperhitungkan IndeksIndeks Keseimbangan. Pada beberapa tulisan Indeks ini juga disebut Indeks Kemerataan. Indeks tersebut antara lain:

$$
\begin{aligned}
& \text { Indeks Pielou }\left[\mathrm{E}_{1}=\{\mathrm{H} / \mathrm{ln}(\mathrm{S})\}\right] \\
& \text { Sheldon }\left[\mathrm{E}_{2}=\left(\mathrm{e}^{\mathrm{H} / \mathrm{S}}\right)\right] \\
& \text { Heip }\left[\mathrm{E}_{3}=\left\{\left(\mathrm{e}^{\mathrm{H}}-1 /(\mathrm{S}-1)\right\}\right]\right. \\
& \text { Hill }\left[\mathrm{E}_{4}=\left\{(1 / \lambda) / \mathrm{e}^{\mathrm{H}}\right\}\right] \\
& \text { Modifikasi dari Hill }\left[\mathrm{E}_{5}=\{(1 / \lambda)-1\} /\left(\mathrm{e}^{\mathrm{H}}-1\right)\right] \\
& \text { mana: } \\
& \mathrm{S}=\text { banyak jenis } \\
& \mathrm{H}=\text { Indeks Shannon }
\end{aligned}
$$$$
\text { di mana: }
$$

$$
\begin{aligned}
& \lambda=\text { Indeks Simpson } \\
& \mathrm{e}=\text { bilangan natural }
\end{aligned}
$$

Analisis hasil penelitian lebih terfokus pada Indeks Shannon $(H)$, Indeks Simpson $(\lambda)$ atau Indeks Dominasi (D), dan Indeks Keseimbangan (E1; Pielou). Sementara itu, sisa digunakan sebatas bench mark bagi hasil kajian yang serupa. Sedangkan kepadatan ikan karang merupakan perhitungan jumlah individu per satuan luas transek (10 mx70 m). Semua prosedural untuk perhitungan di atas menggunakan prinsip-prinsip Microsoft Excel.

Untuk menganalisis kondisi kesehatan karang berdasarkan pada kehadiran ikan indikator (Chaetodontidae) digunakan Irian Jaya Reef Diversity Index, di mana persamaan IRDI=Cx/41x100\%. Cx adalah jumlah jenis ikan indikator yang terdapat di suatu lokasi. Kondisi karang yang sehat memiliki nilai $\mid R D I \geq 75 \%$, sementara kondisi yang buruk memiliki nilai IRDI $\leq 30 \%$ (Nash, 1989).

\section{HASIL DAN BAHASAN}

\section{Komunitas dan Potensi Ikan Karang}

Hasil sensus visual pada lahan transek dideskripsikan secara lebih lengkap pada Tabel Lampiran 1. Lampiran ini menunjukkan bahwa pada Pulau Penata Besar, Lemukutan, dan Pulau Kabung yang termasuk wilayah Kalimantan Barat telah berhasil diidentifikasi sekurang-kurang 81 jenis ikan karang, baik itu tergolong kelompok ikan target, ikan mayor, maupun ikan indikator. Sedangkan Tabel 2 menunjukkan ringkasan dari hasil analisis data sensus tersebut.

Tabel 2 menunjukkan bahwa komunitas ikan karang di Pulau Lemukutan (stasiun 2) relatif lebih baik dibanding Pulau Penata Besar dan Kabung. Hal ini, ditunjukkan oleh jumlah jenis yang ditemukan (51 spesies) dan indeks keragaman ikan karang $(\mathrm{H}=3)$. Namun, jika dibandingkan dengan wilayah karang lain terutama yang memiliki perairan jernih dengan indeks $\mathrm{H}>3$, keanekaragaman ikan karang di wilayah Kalimantan Barat tersebut sangat rendah. Contoh perairan karang kepulauan Banda Maluku, ikan karang di sini sekurang-sekurang ada 388 spesies dengan Indeks $\mathrm{H}$ di atas 3,5 (Edrus et al., 1992). 
Tabel 2. Kondisi ikan karang di Pulau Penata Besar, Pulau Lemukutan, dan Pulau Kabung, Perairan Kalimantan Barat, menurut stasiun penelitian

Table 2. The state of coral fish in the Islands of Penata Besar, Lemukutan, and Kabung, West Kalimatan coastal water, by study sites

\begin{tabular}{|c|c|c|c|c|c|}
\hline \multirow{3}{*}{ No. } & \multirow{3}{*}{$\begin{array}{l}\text { Katagori } \\
\text { (Catagories) }\end{array}$} & \multicolumn{4}{|c|}{ Stasiun (Station) } \\
\hline & & 1 & 2 & 3 & 4 \\
\hline & & $\begin{array}{l}\text { S 00॰45’77,9”' } \\
\text { E 108 } 45^{\prime} 4,3^{\prime \prime}\end{array}$ & $\begin{array}{l}\text { S } 00^{\circ} 48^{\prime} 07,0^{\prime \prime} \\
\text { E } 108^{\circ} 41^{\prime} 56,0^{\prime \prime}\end{array}$ & $\begin{array}{l}\text { S } 00^{\circ} 50^{\prime} 24,0^{\prime \prime} \\
\text { E 108 } 18^{\circ} 47^{\prime} 04,0^{\prime \prime}\end{array}$ & $\begin{array}{l}\text { S } 00^{\circ} 49^{\prime} 76,7^{\prime \prime} \\
\text { E } 108^{\circ} 46^{\prime} 46,8^{\prime \prime}\end{array}$ \\
\hline & (Disciption of Fish Taxonomy) & & & & \\
\hline 1.1. & Jumlah jenis Species number) & 36 & 51 & 43 & 45 \\
\hline 1.2. & Jumlah marga Genus number) & 26 & 38 & 31 & 29 \\
\hline 1.3. & Jumlah suku Family number) & 13 & 14 & 14 & 12 \\
\hline 2. & $\begin{array}{l}\text { Kondisi Populasi Ikan: } \\
\text { (Fish Population State) }\end{array}$ & & & & \\
\hline 2.1 . & Richness Index, Margalef: R1 & 4,1 & 5,7 & 4,9 & 4,9 \\
\hline 2.2 . & Menhinick Index: R2 & 0,5 & 0,6 & 0,6 & 0,5 \\
\hline 2.3. & Simpson Diversity Index: Lambda & 0,11 & 0,07 & 0,10 & 0,09 \\
\hline 2.4. & Shannon Diversity Index: $H$ & 2,6 & 3,0 & 2,6 & 2,7 \\
\hline 2.5 . & Hill's diversitry Number: $\mathrm{N} 1$ & 13,6 & 21 & 13,8 & 15,4 \\
\hline 2.6. & Hill's diversitry Number: N2 & 9,1 & 14,0 & 9,6 & 11,4 \\
\hline 2.7. & Evenness Index: E1 & 0,73 & 0,77 & 0,70 & 0,70 \\
\hline 2.8. & Evenness Index: E2 & 0,38 & 0,40 & 0,32 & 0,34 \\
\hline 2.9. & Evenness Index: E3 & 0,35 & 0,39 & 0,29 & 0,32 \\
\hline 2.10 . & Evenness Index: E4 & 0,66 & 0,67 & 0,69 & 0,74 \\
\hline 2.11 . & Evenness Index: E5 & 0.64 & 0,65 & 0,67 & 0,72 \\
\hline 2.12 . & Jumlah Individu (ndividual number) & 5.168 & 6.685 & 5.247 & 7.458 \\
\hline 2.13 . & Kepadatan(individual/m²) & 10 & 13 & 11 & 15 \\
\hline 3. & $\begin{array}{l}\text { Pengelompokan Status ikan: } \\
\text { (Fish Grouping) }\end{array}$ & & & & \\
\hline 3.1. & Percentage of the major fishes (M; \%) & 73 & 58 & 68 & 73 \\
\hline 3.2. & Percentage of the target fishes $(\mathrm{T} ; \%)$ & 13 & 33 & 11 & 11 \\
\hline 3.3. & Percentage of indicator fishes (I; \%) & 14 & 9 & 21 & 16 \\
\hline 4. & Ikan Indicator (Indicator Fishes) & & & & \\
\hline 4.1. & IRDI Index (\%) & 9,8 & 14,6 & 9,8 & 9,8 \\
\hline 4.2 . & Jumlah jenis Species number) & 4 & 6 & 4 & 4 \\
\hline 5 & Status Ekonomi lkan: & & & & \\
\hline & $\begin{array}{l}\text { (Fish Economic Valuing) } \\
\text { Ikan ekonomis rendah (Low valuable }\end{array}$ & & & & \\
\hline 5.1. & fishes) \% & 68 & 56 & 68 & 73 \\
\hline & Ikan ekonomis sedang ( Fair valuable & & & 10 & 10 \\
\hline J.2. & $\begin{array}{l}\text { tishes) \% } \\
\text { Ikan ekonomis tinggi ( High valuable }\end{array}$ & 18 & 31 & 10 & 10 \\
\hline 5.3. & fishes) \% & 14 & 13 & 22 & 17 \\
\hline
\end{tabular}

Sumber/Source: Data primer survei lapang, bulan Juni 2004 (The primary data of 2004-June Field Survey)

Kondisi terumbu karang yang cukup baik (Tabel 1) pada lahan penelitian tidak cukup berarti untuk mendukung keanekaragaman jenis ikan di perairan karang Kalimantan Barat. Sebagaimana diketahui bahwa terumbu karang menyediakan berbagai habitat dan relung (niche) untuk ikan karang, sehingga memenuhi syarat untuk mendukung beranekaragam jenis ikan. Tetapi mengapa paradoks ini terjadi? Di mana status tutupan karang cukup tinggi, sementara keanekaragam jenis ikan rendah. Belum dapat dipastikan apakah kekeruhan air laut yang tinggi berpengaruh terhadap distrubusi ikan-ikan karang di perairan Kalimantan Barat. Banyak jenis ikan karang yang tidak hadir di lahan tersebut dan mungkin pengaruh sedimentasi dari daratan yang cukup besar menjadi barrier geografis bagi ikan karang. Sehingga hanya 
sebagian kecil jenis ikan karang yang dapat bertahan pada kondisi demikian, meskipun diakui bahwa distribusi ikan karang di daerah tropis dapat digeneralisasikan untuk semua terumbu karang. Tetapi kondisi lokal yang spesifik, seperti pengaruh ada ekosistem pendukung yang lain (contoh mangrove dan padang lamun) atau terjadi pencemaran air laut, dapat membuat komposisi jenis ikan karang di suatu lahan terumbu karang menjadi berbeda antara satu tempat dengan tempat yang lain.

Indeks dominasi (D) yang kecil dan indeks kesimbangan (E) yang cukup baik untuk masing-masing stasiun (Tabel 2) menunjukkan bahwa tidak ada ledakan populasi dan gangguan lingkungan secara fisik pada komunitas ikan. Masing-masing populasi mempunyai kesempatan untuk berkembang dengan baik. Populasi yang cukup melimpah $\left(\mathrm{N}_{1}\right)$ ditemukan 13 sampai dengan 21 jenis, sedangkan populasi yang sangat melimpah $\left(\mathrm{N}_{2}\right)$ ditemukan 9 sampai dengan 14 jenis (Tabel Lampiran 1). Kelompok populasi yang melimpah ini pada umumnya adalah golongan ikan-ikan yang memang berkoloni, seperti ikan ekor kuning dan gete-gete. Karena itu, kondisi ini tidak digolongkan dominasi satu populasi atas populasi lain. Rata-rata kepadatan individu komunitas ikan karang per $\mathrm{m}^{2}$ relatif kecil, yaitu antara 10 sampai dengan 15 individu, sehingga secara visual terumbu karang seolah-olah sepi penghuni.

Ikan-ikan penghuni sejati terumbu karang (group major) hadir dalam persentasi yang lazim, berkisar antara 58 sampai dengan 73\%. Golongan ini di wakili oleh suku Apogonidae, Blenniidae, Labridae, Pinguipedidae, Pomacanthidae, dan Pomacenridae. Komposisi yang cukup baik antara ikan mayor dan target ditemukan pada Pulau Lemukutan (stasiun 2), sehingga pulau ini selain kaya akan ikan mayor, juga kaya akan ikan target tangkapan nelayan. Ikan-ikan yang tergolong target tangkapan nelayan dan dijumpai di lokasi penelitian meliputi suku Holocentridae (Murjan, Brajanata), Serranidae (Kerapu), Nemipteridae (Gurisi), Haemulidae (Rajabau), Lutjanidae (Bambangan), Caesionidae (ekor kuning, pisang-pisang), Kyphosidae (Kemplang), Scaridae (Kakatua), dan Siganidae (Baronang). Namun demikian, tidak semua jenis dari suku di atas hadir pada lahan terumbu karang di perairan Kalimantan Barat.

Golongan ikan indikator (Chaetodontidae) pada semua lahan transek dijumpai dalam jumlah jenis yang sangat kecil (4 sampai 6 species), tetapi jumlah individu relatif besar. Irian Jaya Reef Diversity Index pada masing-masing stasiun (9,8 sampai dengan $14,6 \%)$ tidak signifikan untuk digunakan dalam penentuan kondisi kesehatan karang. Sebab pada kenyataan tutupan karang batu ditemukan cukup tinggi di lokasi penelitian. Rendah jumlah jenis ikan indikator tersebut mungkin berkaitan dengan ada dominasi bentukan karang masive. Sebaliknya, jumlah individu ikan indikator yang besar (antara 682 sampai dengan 2.204 per $500 \mathrm{~m}^{2}$ ) menunjukkan signifikasi yang cukup untuk petunjuk kesehatan karang (Tabel 2).

Tabel 2 juga menunjukkan nilai ekonomi perairan karang di setiap lokasi penelitian, yaitu besar persentasi ikan karang yang memiliki harga jual dari mulai tinggi sampai dengan rendah. Berapa besar nilai komoditi ikan karang sangat ditentukan oleh kemampuan beli masyarakat (willing to pay) dan karakteristik dari komoditi itu sendiri. Karakteristik komoditi yang menentukan nilai ekonomis ikan-ikan ini didasarkan pada a) jika ikan pangan (ikan target), maka permintaan pasar akan jenis itu apakah tinggi, sedang, atau rendah; dan b) jika ikan hias (baik ikan mayor atau ikan indikator), nilai sangat ditentukan dari warna, bentuk, gerakkangerakkan yang anggun dan unik, kelangkaan jumlah di terumbu karang, ada usaha, dan tujuan pasar (apa untuk ekspor atau pasar domestik). Pada Lampiran daftar ikan hasil sensus dapat dilihat penggolongan nilai ikan, seperti jenis apa yang mempunyai nilai rendah $\left({ }^{*}\right)$, jenis yang bernilai ekonomis sedang $\left({ }^{* *}\right)$, dan jenis yang bernilai ekonomis tinggi $\left(^{* \star \star}\right)$. Tabel 2 menunjukkan hasil kesimpulan dari penggolongan tersebut dalam bentuk persentasi. Jenis-jenis ikan karang yang memiliki harga tinggi tergolong dalam suku Chaetodontidae dan Pomacantidae. Jenis ikan yang tergolong dalam suku ini merupakan ikan-ikan hias yang menarik dan komoditas ekspor (Gambar 2). Sedangkan dari golongan ikan target yang memiliki nilai ekonomis tinggi adalah suku Serranidae (Kerapu) yang juga merupakan komoditas ekspor. Golongan ikan target lain yang memiliki nilai ekonomis sedang meliputi Nemipteridae (gurisi), Haemulidae (rajabau), Lutjanidae (bambangan), Caesionidae (ekor kuning, pisang-pisang), dan Kyphosidae (kemplang). Sebagian besar kelompok bernilai ekonomis rendah adalah ikan-ikan kelompok mayor yang tergolong ikan-ikan hias yang kurang digemari atau kurang menarik.

Gambar 2 menunjukkan bahwa betapa sedikit ikanikan yang tergolong memiliki harga jual tinggi di wilayah perairan ke-3 pulau tersebut. Oleh karena itu, untuk mendapatkan kelengkapan data jenis ikan perlu ada monitoring berkala berdasarkan pada musim. 


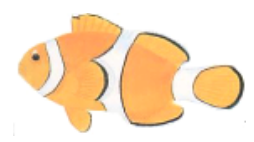

Amphiprion ocellaris

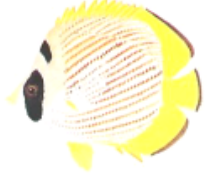

Chaetodon adiergastos

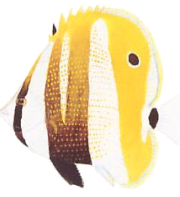

Coradion hrysozonus

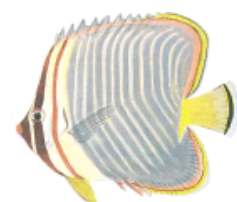

Chaetodon aronessa

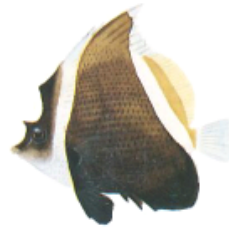

Heniochus arius

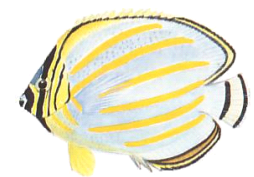

Chaetodon ornatissimus

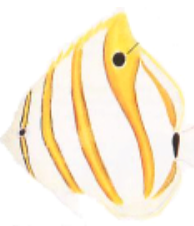

Parachaetodon ocellatus

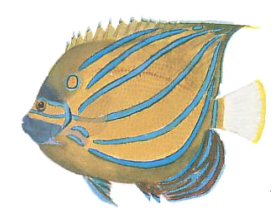

Pomacanthus annularis

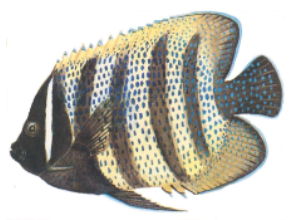

Pomacanthus exstriatus

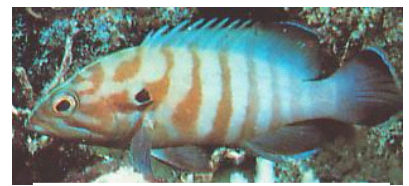

Cephalopholis boenack

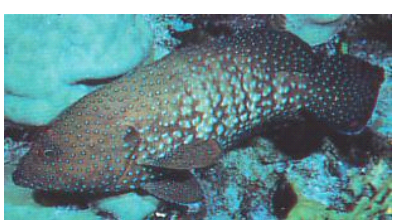

Cephalopholis yanostigma

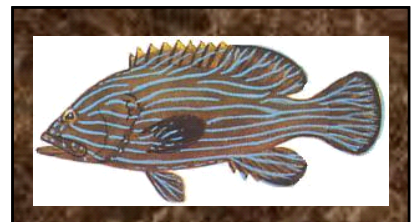

Cephalopholis formosa

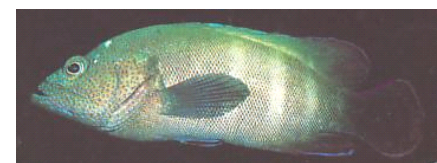

Cephalopholis microprion

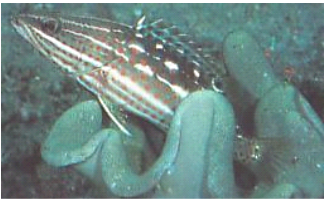

Anyperodonl eucogrammicus

Gambar 2. Ikan-ikan ekonomis penting yang teridentifikasi di lahan terumbu karang Pulau Penata Besar, Lemukutan, dan Kabung, Kalimantan Barat.

Figure 2. The economic valuable fishes identified on the reef areas of Penata Besar, Lemukutas, and Kabung Islands, West Kalimantan.

Secara visual, survei pada bulan Juni 2004 ini menunjukkan suatu fenomena perairan karang dengan kondisi jarang pandang (visibility) horisontal yang rendah dan tingkat keanekaragaman ikan yang rendah pula. Pada saat survei tersebut, kondisi setempat berada pada musim panas di mana curah hujan sangat kecil. Hal ini, dapat berarti bahwa massa air daratan kurang pengaruh terhadap kekeruhan perairan pantai. Namun demikian, pada saat survei tersebut tingkat kekeruhan air cukup tinggi, di mana kecerahan yang terukur di lokasi transek 4 sampai dengan $6 \mathrm{~m}$ dan jarak pandang horisontal di dalam badan air 5 sampai dengan $7 \mathrm{~m}$. Sehingga dapat diprediksi bahwa pada saat musim hujan dampak kekeruhan akan semakin buruk pada lingkungan perairan pantai, sehingga kondisi yang kurang menguntungkan ini menjadi berkepanjangan dan sangat berpengaruh pada berbagai organisme laut. 
Secara umum, dapat dikatakan bahwa perairan karang di Kalimantan Barat miskin akan ikan karang, walaupun pertumbuhan karang batu pada perairan ini cukup baik. Oleh karena itu, seperti telah dipertanyakan di atas bahwa mengapa kondisi karang batu yang sehat tidak berkorelasi secara signifikan terhadap tingkat keanekaragaman ikan-ikan karang? Seperti diketahui bahwa di samping tersedia berbagai habitat atau relung (niche) untuk ikan karang, faktor ketersediaan makanan, stabilitas lingkungan, dan interaksi organisme dengan lingkungan juga harus diperhitungkan sebagai penyebab hadir beranekaragam ikan karang. Pada kenyataan bahwa observasi di lahan transek menunjukkan absen berbagai jenis ganggang laut di lokasi penelitian. Selain itu, lahan karang tersebut juga tidak berbatasan dengan ekosistem penunjang lain seperti padang lamun (sea grass bed) yang memiliki beranekaragam ganggang (algae) dan tumbuhan lamun atau mangrove yang memiliki serasah sebagai sumber makanan. Makro alga yang hidup di dasar perairan pada umumnya menjadi mata rantai pertama dalam jaring-jaring makanan (Gomez \& Yap, 1988). Sedangkan menurut Randall (1965), beberapa jenis ikan (grazers) merupakan pemakan langsung daun lamun, seperti ikan kakatua, butana, baronang, dan koja.

Ikan adalah organisme yang relatif lebih kompleks, di mana banyak aspek biologi dan perilaku dapat digunakan untuk mengukur tingkat kesesuaian habitat. Kehadiran atau ketidakhadiran jenis-jenis tertentu adalah juga petunjuk yang akurat dalam kasus-kasus tertentu (misal pencemaran dan ketiadaan makanan), karena kemampuan ikan dapat berpindah-pindah, ikan dapat keluar dari wilayah tetap untuk memilih habitathabitat dengan keadaan yang lebih menguntungkan. Lahan terumbu karang dengan kekeruhan yang kronis melampaui periode waktu yang panjang, serta dengan kondisi vegetasi dan keragaman jenis karang yang rendah dapat berpengaruh terhadap komposisi jenis ikan yang hadir. Perubahan-perubahan dalam distribusi, komposisi, dan kelimpahan ikan karang dapat menjadi petunjuk ada gangguan pada habitat dan rantai makanan. Pendapat Emery (1978) di bawah ini dapat memperkuat pernyataan di atas, bahwa keanekaragaman jenis berbanding terbalik dengan tingkat gangguan, dan berbanding lurus dengan jumlah radiasi sinar matahari, tersedia makanan dan beragam habitat. Sejalan dengan pendapat di atas, maka dapat dimengerti jika perairan karang di lokasi penelitian tersebut mempunyai keanekaragaman jenis yang rendah.

Dalam hubungan dengan kebiasaan makan ikan karang, menurut Nybaken (1988), 50 sampai dengan $70 \%$ dari jenis ikan tergolong karnivora yang oportunistik. Banyak jenis ikan-ikan yeng tergolong karnivora tidak terlihat di lokasi penelitian, seperti jenisjenis ikan yang tergolong suku Serranidae (kerapu), Scorpaenidae (lepu batu atau lepu ayam), Haemulidae (bibir tebal atau raja bau), dan Carangidae (kuwe dan barakuda). Kemudian, 15\% tergolong herbivora dan pemakan karang, seperti ikan-ikan kakatua (Scaridae), sekartaji atau butana (Acanthuridae), baronang (Siganidae), mendut (Balistidae), kinang atau brajanata atau surendang (Holocentridae), buntal kotak (Ostraciidae), ikan ayam (Tetraodontidae), dan ikan betok (Pomacentridae). Dalam kasus ini, hanya sebagian kecil jenis ikan kakatua (4 jenis) yang teridentifikasi di lokasi transek, seperti juga baronang (2 jenis). Sedangkan ikan-ikan yang tergolong dalam suku Acanthuridae, Balistidae, Holocentridae, Ostraciidae, dan Tetraodontidae tidak ada (absen) pada lahan transek. Sisa sebagian kecil tergolong omnivora atau multivora (pemakan segala), seperti kepe-kepe (Chaetodontidae, hanya 7 jenis yang ditemukan di lokasi transek), Injel (Pomacanthidae, hanya 2 jenis ditemukan) betok atau giru (Pomacentridae, hanya 19 jenis), ikan tato atau kipas (Monacanthidae, absen), buntel duren (Diodontidae, absen), dan banyak lagi suku-suku ikan karang yang tidak terlihat di lokasi transek. Hal ini, menunjukkan begitu rendah potensi jenis ikan karang di lahan terumbu karang ke-3 pulau tersebut.

Kondisi komunitas ikan karang secara umum disimpulkan pada Tabel 2. Indeks-indeks ekologis pada Tabel 2 merupakan data spasial populasi ikan karang yang membedakan komunitas ikan di antara lahan terumbu karang pada beberapa stasiun, walaupun perbedaannya relatif kecil sekali. Data ini telah memberikan kondisi populasi ikan karang yang representatif bagi informasi geografis dan valuasi potensi terumbu karang. 


\section{KESIMPULAN}

Beberapa hal yang dapat disimpulkan dari hasil penelitian ini antara lain:

1. Jumlah jenis ikan karang pada perairan karang pulau Penata Besar, Lemukutan, dan Pulau Kabung sangat rendah.

2. Indeks kekayaan dan keanekaragaman jenis ikan karang rendah, di mana indeks R1 di bawah 6 dan indeks $\mathrm{H}$ di bawah 3. Sedangkan keseimbangan populasi di dalam komunitas cukup baik, artinya tidak ada faktor-faktor lingkungan yang ekstrim yang dapat menghambat perkembangan masing-masing populasi yang telah eksis di lahan tersebut.

3. Banyak jenis, marga, dan suku ikan karang yang hadir di terumbu karang tidak tampak hadir pada ke-3 pulau tersebut. Kemungkinan yang menjadi faktor penyebab adalah kekeruhan air yang tinggi dan faktor ketersediaan makanan.

4. Komposisi kelompok ikan mayor sebagai penghuni karang sangat dominan dibanding dengan kelompok ikan target dan ikan indikator.

5. Irian Jaya Reef Diversity Index untuk indikator keragaman karang batu sangat rendah, tetapi jumlah individu ikan indikator sendiri cukup tinggi.

6. Jenis-jenis ikan karang yang bernilai ekonomis tidak banyak dijumpai di ke-3 pulau.

7. Kekeruhan perairan yang tinggi merupakan pembatas bagi keanekaragaman ikan karang.

\section{SARAN}

1. Tinggi suspendid solid akibat kekeruhan ini perlu dipertimbangkan dalam interpretasi citra satelit, karena pada kenyataan terumbu karang tumbuh dengan baik di lokasi penelitian, walaupun keberadaan secara kasat mata tidak tampak terlihat dari permukaan air setinggi $1 \mathrm{~m}$.

2. Penelitian lanjutan dan atau monitoring dan evaluasi baik dilakukan secara periodik, khusus pada berbagai musim.

\footnotetext{
Persantunan

Hasil dari kegiatan riset: Pemetaan Sumber Daya

Pesisir Pantai T.A. 2004 di Bakorsurtanal
}

\section{DAFTAR PUSTAKA}

Edrus, I. N., A. R. Syam, \& La Sui. 1992. Potensi, pemanfaatan, dan prospek pengembangan perikanan karang di Kepulauan Banda, Maluku Tengah dalam hubungannya dengan kepariwisataan. Jurnal Penelitian Perikanan Laut. 74: 40-60.

Emery, A. R. 1978. The basis of fish community structure: Marine and freshwater comparaisons. Environmental Biology Fishery. 3 (1): 33-47.

English, S., C. Wilkinson, \& V. Baker.1994. Survey manual for tropical marine resources. Australian Institute of Marine Science. Townsville. Australia.

Gomez, E. D. \& H. T. Yap. 1988. Monitoring reef condition. In Coral reef management handbook. R. A. Kechington \& B. E. T. Hudson (Eds). UNESCO Publisher. Jakarta. p 171.

Kuiter, R. H. 1992. Tropical reef fishes of the Western Pacific Indonesia and adjacent waters. Gramedia. Jakarta.

Kunzmann, A. 2004. Corals, fishermen, and tourists. NAGA. World Fish Centre Quarterly. Vol.27 (1\&2): 15-19.

Lieske, E. \& R. Myers. 1997. Reef fishes of the world. Periplus Edition. Jakarta. Indonesia.

Ludwig, J. A. \& J. F. Reynolds. 1988. Statistical ecology. A Primer on Methods and Computing. Jhon Wiley \& Son. New York. 337 p.

Nash, S.V. 1989. Reef diversity index survey method for non sspecialist. Tropical Coastal Area Management. Vol.4 (3): 14-17.

Nybakken, J. W. 1988. Biologi laut suatu pendekatan ekologis (Terjemahan Muhammad, Eidman, Koessoebiono, Dietriech G. B., Malikusworo Hutomo, \& Sukristijono). Penerbit PT. Gramedia. Jakarta.

Randall, J. E. 1965. Grazing effect on seagrass by herbivorous reef fishes in the West Indies. Ecology. 46 (3): 255-260.

White, A. T. 1987. Coral reefs: Valuable resources of Southeast Asia. ICLARM Education Series 1, Manila. Philippines.

Diterima tanggal: 3 Pebruari 2005

Diterima setelah perbaikan tanggal: 17 Juni 2005

Disetujui terbit tanggal: 17 Juni 2005 


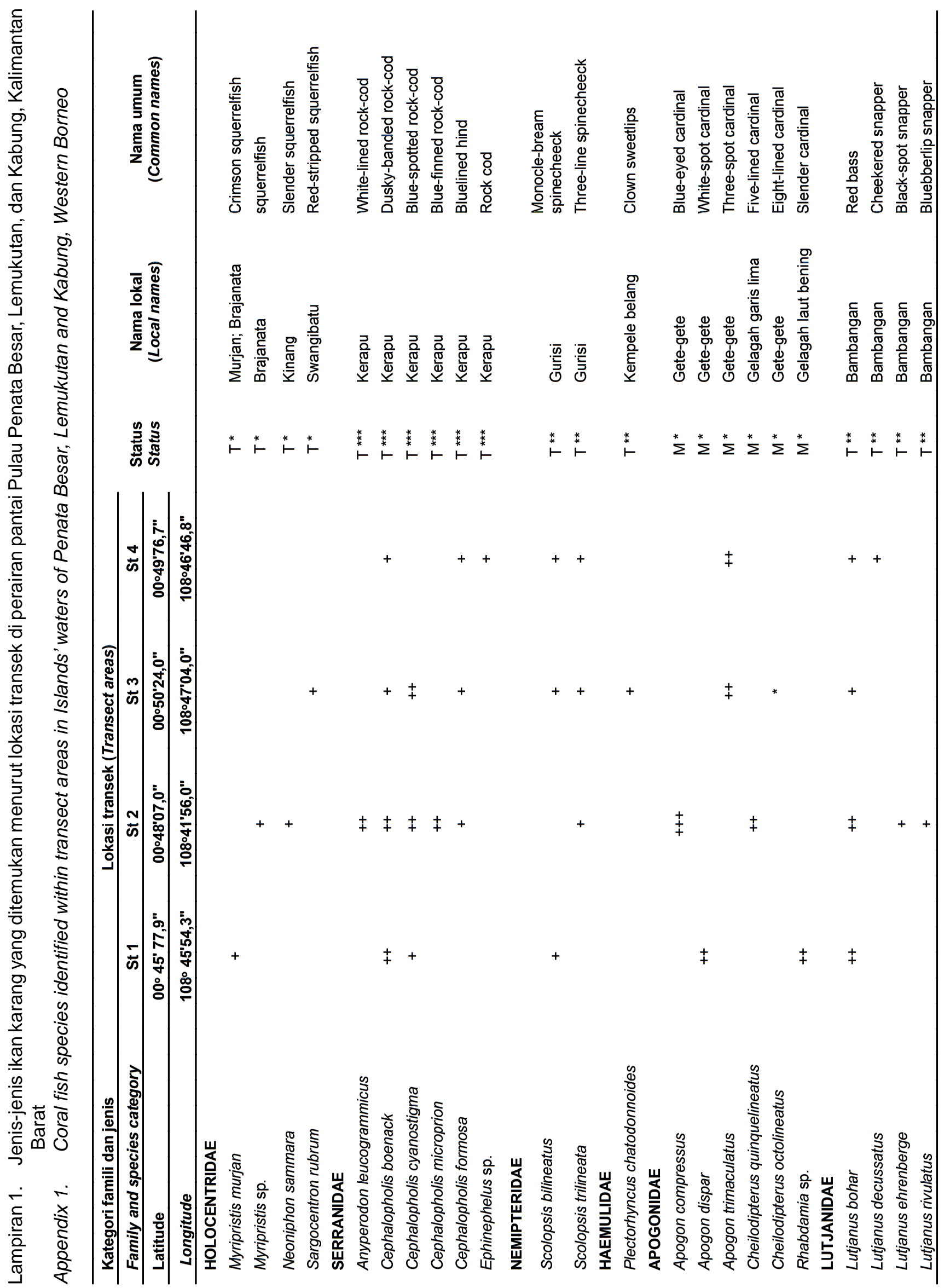




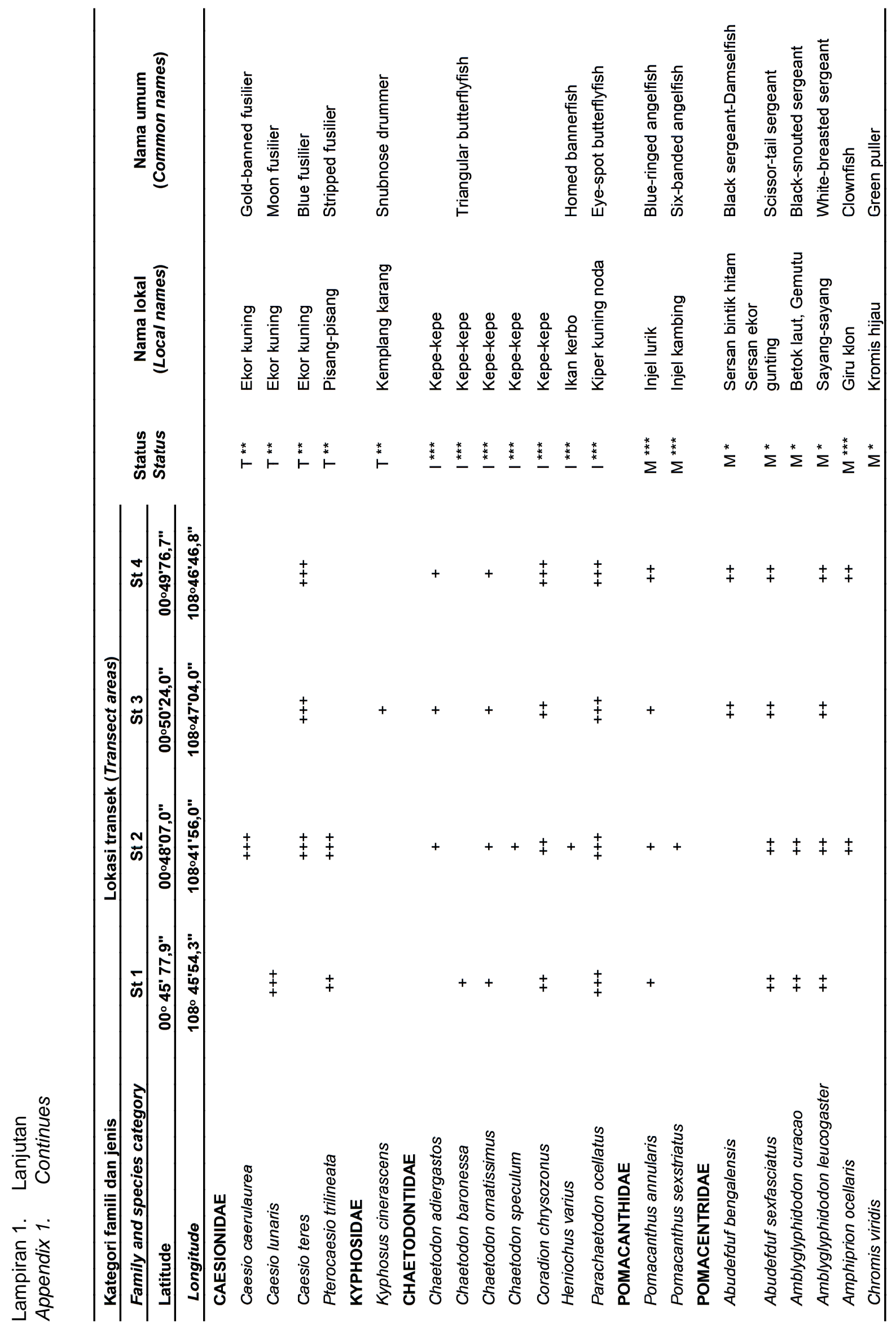




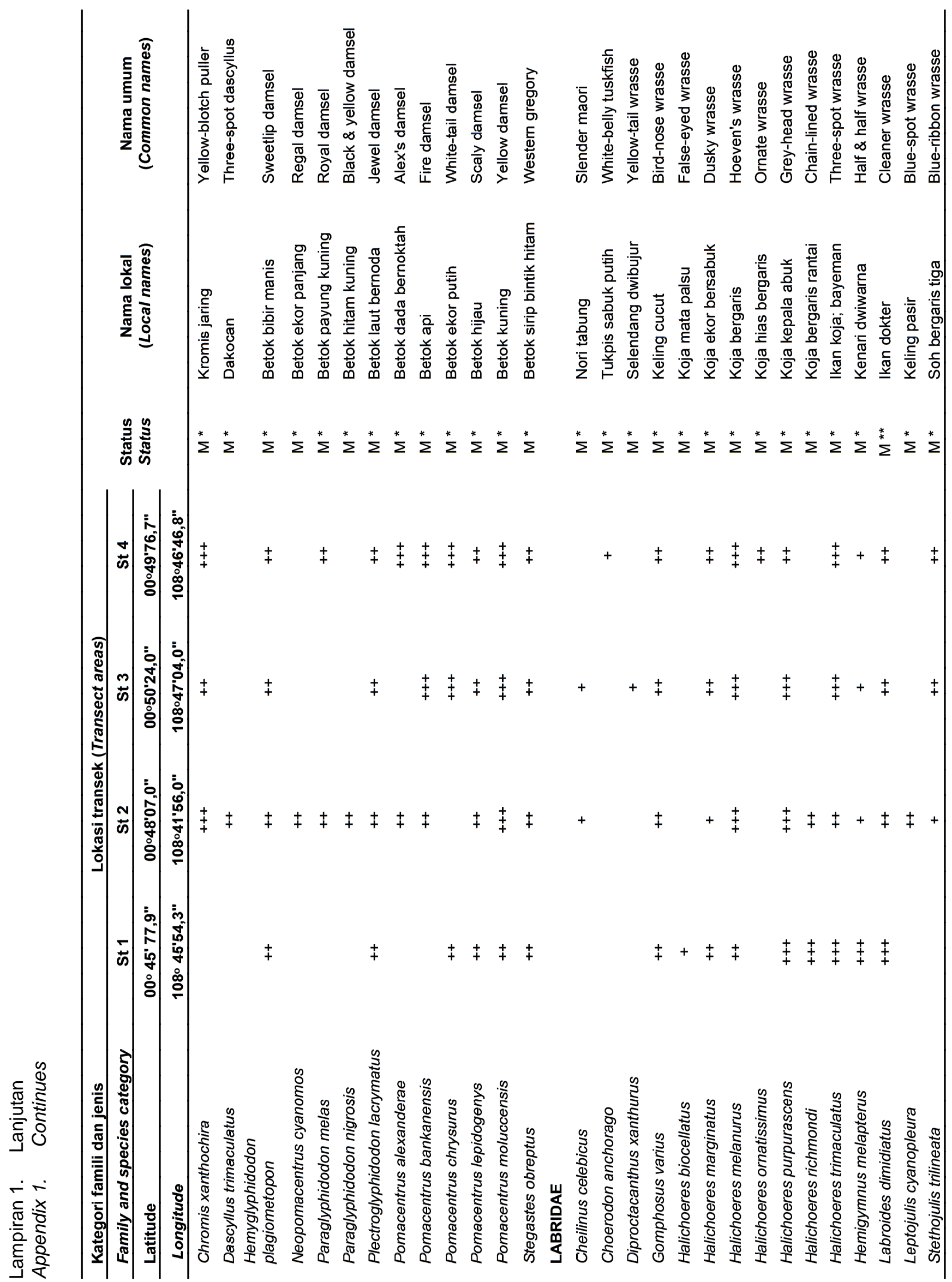




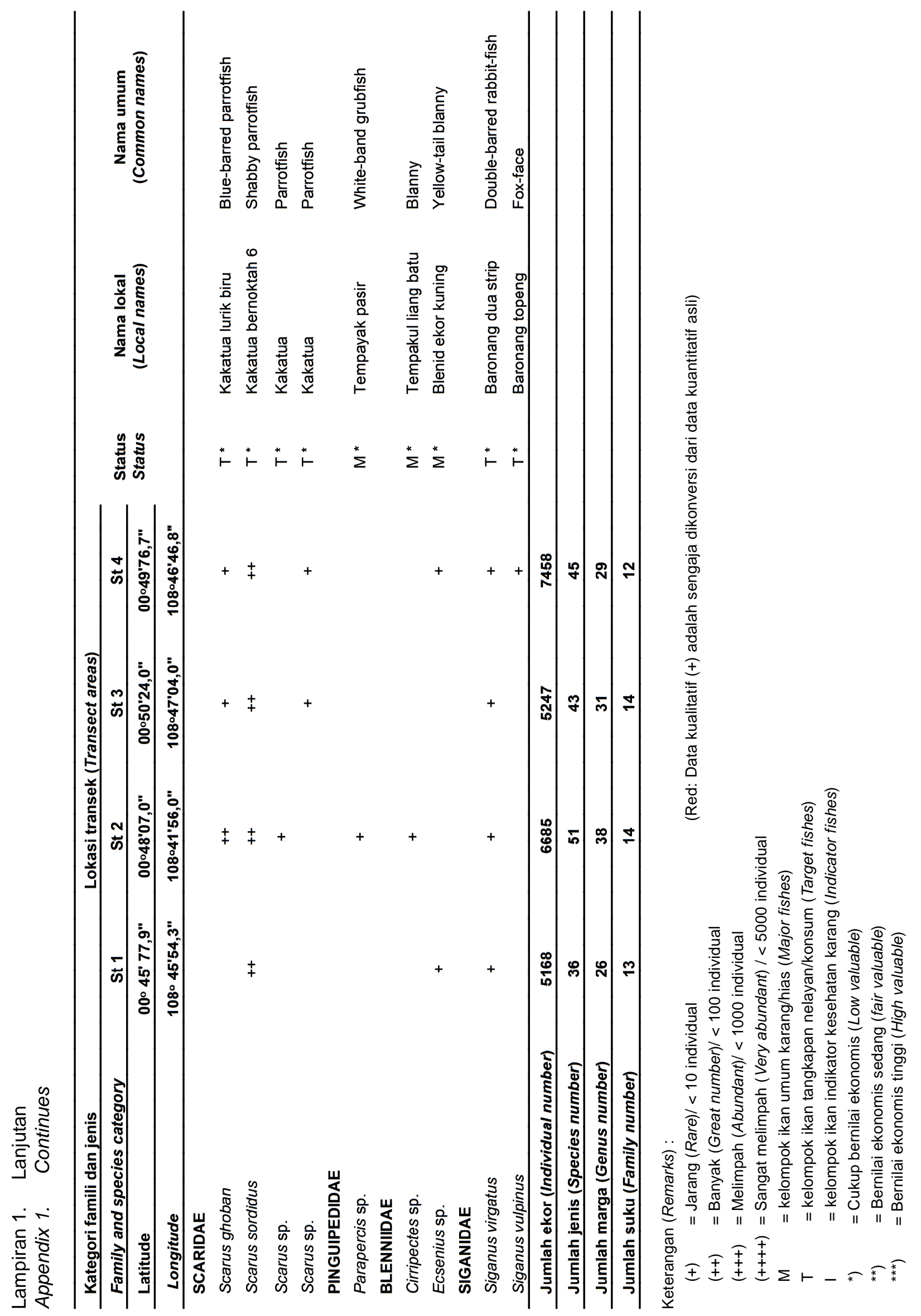

